\title{
Genetics of Yellow Mosaic Virus Disease Resistance in Soybean (Glycine max L. Merr.)
}

\author{
S. Baruah ${ }^{1,2}$, M.K. Sarma ${ }^{1 *}$ and D. Baishya ${ }^{2}$ \\ ${ }^{1}$ Biotech Hub, BN College of Agriculture, Assam Agricultural University, Biswanath Chariali, \\ Assam-784176, India \\ ${ }^{2}$ Department of Bioengineering and Technology, Gauhati University, Guwahati, \\ Assam-781014, India \\ *Corresponding author
}

\begin{tabular}{|c|}
\hline Keywords \\
\hline $\begin{array}{l}\text { Soybean, Yellow Mosaic } \\
\text { Virus Disease, } \\
\text { Resistance, Inheritance, } \\
\text { Monogenic Dominance }\end{array}$ \\
\hline Article Info \\
\hline $\begin{array}{l}\text { Accepted: } \\
26 \text { July } 2018 \\
\text { Available Online: } \\
10 \text { August } 2018\end{array}$ \\
\hline
\end{tabular}

A B S T R A C T

Yellow Mosaic Virus disease (YMD) is a serious viral disease of soybean. Considering a very less attempt in studying the disease this investigation was carried out in order to arrive at the genetic basis of Yellow Mosaic Virus disease resistance of soybean. Crosses were made between highly resistant soybean varieties (DS 9712 and DS 9814) and two highly susceptible varieties (JS 335 and MAUS 609). The four cross combinations were MAUS $609 \times$ DS 9712, MAUS $609 \times$ DS 9814, JS $335 \times$ DS 9712 and JS $335 \times$ DS 9814 . All true hybrids of $F_{1}$ population were observed to be resistant with the score zero (0) presenting a clear visible evidence of resistance to be dominant over susceptibility. The $\mathrm{F}_{2}$ plants resulted from all four crosses were observed to segregate for YMD resistance at 3 (Resistance): 1 (Susceptible) ratio indicating the genes for resistance in the concerned parents under study to be monogenic in nature. Chi square $\left(\chi^{2}\right)$ test for all the four crosses showed a good fitness to 3 (Resistance): 1 (Susceptible) ratio in the $\mathrm{F}_{2}$ population at $5 \%$ probability level indicating the monogenic dominance nature of the resistance gene. The present investigation clearly suggests that the YMD resistance trait is governed by a single dominant gene.

\section{Introduction}

Soybean Glycine max (L.) Merr. $(2 \mathrm{n}=40)$ is the unique grain legume known for its dual use as pulse and oilseed providing both quality edible protein (38-44\%) and oil (18-22\%). Although soybean is not commercially grown in North East India, it is quite popular as a source of traditional food among the ethnic communities of this region besides being consumed as soya chunks and oils. Soybean production has been challenged by a number of biotic and abiotic stresses. Among different biotic stresses Yellow Mosaic Virus disease (YMD) is one of the predominant viral diseases, especially in North, North East and Central India causing yield loss as high as 80 $\%$. Yellow Mosaic Virus disease (YMD) is a viral disease transmitted by white fly Bassimia tabacci. The begomovirus causing YMD has two species, viz., Mungbean Yellow Mosaic India Virus (MYMIV) and Mungbean Yellow 
Mosaic Virus (MYMV) (Fauquet and Stanley, 2003). Both MYMIV and MYMV are prevalent in India causing YMD epidemics on various legume crops including mungbean, blackgram, soybean, cowpea, pigeonpea and horsegram (Usharani et al., 2004). The affected plants turn yellow and lose its vigor. In severe cases, the growing tip stops growing and becomes a clump of un-opened leaves. Pod setting gets drastically reduced with eventual loss of yield. The situation demands devising effective control mechanism to sustain rather increase soybean production in the country. The incidence of YMD in soybean is most pronounced in North Eastern India as well as Northern India (Annual Report, AICRP-soybean, 2000 - 2002, 2004 05 and 2005 - 06, 2008 - 09, 2009 - 10). So, further spread of this disease may bring disaster towards soybean industry in our country. Although chemical or cultural strategy for controlling YMV disease is in practice, neither of these approaches are known to be fully effective or environment friendly. Hence, the most advisable way to control Yellow Mosaic Virus infection is the deployment of genetic resistance of the host against the viral pathogen. Having a clear understanding about the inheritance pattern of YMD resistance is prerequisite to design breeding programme leading to the development of YMD resistant lines. The present investigation was undertaken with a view to study the inheritance pattern of resistance against YMD in native location and environmental condition of North Eastern part of India so as to aid in formulating effective resistance breeding programme on soybean for the region.

\section{Materials and Methods}

\section{Material}

Materials for the present investigation comprised of four soybean genotypes with complete resistance and susceptibility for Yellow Mosaic Virus disease viz., DS 9712, DS 9814, JS 335 and MAUS 609. DS 9712 and DS 9814 were two highly resistant varieties against YMD whereas JS 335 and MAUS 609 were highly susceptible ones.

\section{Hybridization to obtain $F_{1}$ plants}

In order to study the inheritance of YMV resistance of soybean selected resistant and susceptible genotypes were used as parents for hybridization programme (Fig. 1). Crosses were performed in different combinations viz., MAUS $609 \times$ DS 9712, MAUS $609 \times$ DS 9814, JS $335 \times$ DS 9712 and JS $335 \times$ DS 9814 (Table 1) by performing pollination without emasculation as described by Talukdar and Shivakumar, (2012). Selection of flower for hybridization is of prime importance in an artificial crossing programme. The flowers, which are going to open in the next morning, were selected for hybridization. Moreover, the season of crossing also affects the success of hybridization. Warm weather favors successful hybridization while crossing performed in winter leads to wrong selection of flower buds for crossing. Mature pollen was extracted from selected fully opened fresh flower to pollinate the flower bud. The pollination was performed early morning. The selected flower bud was made ready for pollination by carefully removing the sepals and exposing the ring of stamens. The yellow colored dusty pollen was then distributed on stigma carefully. The buds were covered with moist cotton to prevent drying of stigma. The plants were tagged properly after pollination. A large number of $F_{1}$ seeds were obtained from the crosses.

\section{Test of hybridity}

In order to test whether the plants developed from a $F_{1}$ seed is hybrid or self-fertilized, 
hybridity of the $F_{1}$ plants was tested. For this purpose, a set of two markers viz., Satt177 and Satt656 was selected which showed polymorphism between parents.

The genomic DNA extracted from the parents was amplified with these two markers. Plants producing two bands each corresponding to maternal and paternal genotype were identified as true hybrid and rests were rejected as self-fertilized plants.

Scoring of genotypes for yellow mosaic disease resistance in $\mathbf{F}_{1}$

Four $F_{1}$ populations obtained along with the parental crops were grown in the experimental field of $\mathrm{B} N$ College of Agriculture in randomized block design with a spacing of 30 $\mathrm{cm}$ between rows and $10 \mathrm{~cm}$ between plants. Spreader rows of highly susceptible varieties were sown after each five rows to maintain uniform disease pressure. $F_{1}$ plants were scored for disease incidence following zero to nine (0-9) scale (Lal et al., 2005) (Table 2). Scoring of the plants for disease reactions was done only when the plants in the 'spreader rows' were turned complete yellow due to the disease infection.

Screening for YMD resistance in $F_{2}$ segregation population

Healthy self-fertilized seeds of true $F_{1}$ populations were grown in the experimental field of B N College of Agriculture during Kharif of 2013-14. A total of 200, 150, 112 and 170 number of $F_{2}$ plants obtained from the cross combination MAUS $609 \times$ DS 9712, MAUS $609 \times$ DS 9814, JS $335 \times$ DS 9712 and JS $335 \times$ DS 9814 respectively were screened for YMD resistance. Scoring of the $F_{2}$ plants was done using zero to nine (0-9) scale as per protocol described above. Numbers of resistant and susceptible plants were counted and ratio between them was recorded.

\section{Testing for goodness of Fit}

The recorded resistant and susceptible plants ratios were subjected to $\chi 2$ (Chi-square) tests for goodness of fit at $5 \%$ probability level and significance of the test was studied following Panse and Sukhatme, (1967). The formula used as follows:

$\chi 2($ Chi-square $)=\left(\mathrm{O}_{\mathrm{i}}-\mathrm{E}_{\mathrm{i}}\right)^{2} / \mathrm{E}_{\mathrm{i}}$

Where $\mathrm{O}_{\mathrm{i}}=$ Observed value against ith class, $\mathrm{E}_{\mathrm{i}}=$ Expected value in the ith class.

\section{Results and Discussion}

\section{Test of Hybridity}

Soybean, being a highly self-pollinated crop shows very low level of $0.2 \%$ of out crossing (Talukdar and Shivakumar, 2012). Improper crossing leads to self-pollinated crops. Hence, testing the hybridity of $F_{1}$ plants is a must to ensure successful crossing programme. Both morphological and molecular markers can be used to test the hybridity of test plants.

In the present experiment, all the four cross combinations between susceptible and resistant genotypes generated satisfactory number of $F_{1}$ plants. Further, while testing for true hybrids with polymorphic SSR marker viz., Satt177 and Satt656, ample number of plants exhibited bands corresponding to both paternal and maternal parents indicating successful flower bud selection and crossing. The number of $F_{1}$ plants respective to all four cross combination along with the number of true hybrids are listed in Table 3.

The cross between YMD susceptible genotype MAUS 609 and resistant genotype DS 9712 generated a total of seventy two $F_{1}$ plants among which sixty five were found to be true hybrid. $80 \%$ of total $\mathrm{F}_{1}$ obtained from the cross MAUS $609 \times$ DS 9814 showed true 
hybridity while $83 \%$ of $\mathrm{F}_{1}$ were true hybrid for the cross JS $335 \times$ DS 9712 . The cross JS $335 \times$ DS 9814 generated a total of seventy $F_{1}$ plants among which sixty two plants showed true hybridity. Test of hybridity results revealed high rate of accuracy during the crossing experiment. Results also indicated that the climatic condition of hybridization experiment was appropriate. Talukdar and Shivakumar, (2012) reported that successful crossing depends on the stage of flower bud taken and also on the season of hybridization.

\section{Inheritance study of YMV}

All true hybrids of $F_{1}$ population were observed to be resistant showing the score zero (Table 3). The number of $F_{2}$ plants screened for YMD resistance and number of $\mathrm{F}_{2}$ plants exhibiting resistance and susceptibility against YMD are listed in Table 4. The $F_{2}$ plants resulted from all four crosses were observed to segregate for YMD resistance at clear cut 3 (Resistance): 1 (Susceptible) ratio. Number of resistant plants for the four cross combination are 153, 115, 90 and 123, respectively. On the other hand, in the present investigation, 47, 35, 22 and 47 plants showed susceptibility for YMV among all the $\mathrm{F}_{2}$ plants screened. The disease reaction in the sergeants appeared to be qualitative in nature which was expected based on the contrasting parents taken for the crossing. Appearance of no intermediate sergeants indicated the genes for resistance in the concerned parents under study were monogenic in nature.

Chi square $\left(\chi^{2}\right)$ test for all the four crosses showed a good fitness to 3 (Resistance): 1 (Susceptible) ratio in the $\mathrm{F}_{2}$ population fit at $5 \%$ probability level (Table 5). Under the present investigation, all the $F_{1}$ plants generated through crosses showed resistance against YMV. This presents a clear visible evidence of resistance to be dominant trait over susceptibility. The $\mathrm{F}_{2}$ plants resulted from all four crosses were observed to segregate for YMV resistance at clear cut 3 (Resistance): 1(Susceptible). The entire cross combinations were found to be non-significant when tested against actual 3:1 ratio.

Further, the insignificant $\chi 2$ and high $\mathrm{P}$-value showed complete goodness of fit to the ratio. Hence, results of $F_{2}$ segregation and Chi square $\left(\chi^{2}\right)$ test confirmed that the resistance is governed by single dominant gene. Similar observations that YMD resistance was controlled by single dominant gene was also reported by Bhattacharyya et al., (1999) and Talukdar et al., (2013). However, contrary to this Singh and Mallick, (1978) reported two recessive genes controlling the YMD resistance.

This monogenic dominance pattern of inheritance of resistance against YMD has been reported in other crops like mungbean too (Sandhu et al., 1985; Verma and Singh, 1988, Ammavasai et al., 2004). On the contrary, some reports revealed the dominance of susceptibility over resistance against YMD in Mungbean (Sudha et al., 2013).

They observed dominance of susceptibility over resistance indicating a monogenic recessive inheritance of the resistance. Similar results of single recessive genes inheritance of the MYMV resistance in mungbean have been reported by other workers too (Basak et al., 2004; Saleem et al., 1998). Further, Khattak et al., (2000) mentioned role of some modifying genes monogenic recessive control of YMD resistance in mungbean.

These contradictory results regarding the genetics of YMD may possibly arise from variation of genotypes of host. Difference in viral strain specific to that area may also influence the inheritance pattern. Climatic condition also affects the phenotypic 
appearance of traits among genotypes. Moreover, a susceptible genotype may also be rated as resistant in presence of insufficient disease pressure or uneven spread of the vectors in the field. Although contradictory reports on inheritance of YMD resistance has been reported by various worker, all the experiments were carried out in different region taking different genotypes for studying the inheritance pattern.

Table.1 Cross combination of highly resistant and highly susceptible soybean genotypes for Yellow Mosaic Virus to generate $F_{1}$ generation

\begin{tabular}{|l|l|l|l|l|} 
SI. No. & \multicolumn{4}{|c|}{ Parents } \\
& Female & Disease response & Male & Disease response \\
\hline 1 & DS 9712 & Resistant & MAUS 609 & Susceptible \\
\hline 2 & DS 9814 & Resistant & MAUS 609 & Susceptible \\
\hline 3 & DS 9712 & Resistant & JS 335 & Susceptible \\
\hline 4 & DS 9814 & Resistant & JS 335 & Susceptible \\
\hline
\end{tabular}

Table.2 Scoring criteria for YMD incidence (Lal et al., 2005)

\section{Score Symptom}

\begin{tabular}{|l|l|}
\hline $\mathbf{0}$ & No symptoms on any plant \\
\hline 3 & Yellow mottle on $10 \%$ or fewer plant \\
\hline 5 & $\begin{array}{l}\text { Necrotic mottle on most plants, no reduction in plant growth, no yield loss. } \\
\text { Yellow mottle not covering whole leaf on most plants, reduction in leaf and plant } \\
\text { growth }\end{array}$ \\
\hline 9 & Yellow mottle on most plant, severe reduction in yield, leaf and plant growth. \\
\hline
\end{tabular}

Table.3 Number of true hybrids in $\mathrm{F}_{1}$ population obtained from all four crosses combinations

\begin{tabular}{|c|c|c|c|c|c|}
\hline Cross Combination & $\begin{array}{l}F_{1} \\
\text { Obtained }\end{array}$ & $\begin{array}{l}\text { True } \\
\text { Hybrid } F_{1}\end{array}$ & $\begin{array}{l}\% \\
\text { hybridity }\end{array}$ & Score & YMD response \\
\hline MAUS $609 \times$ DS9712 & 72 & 65 & $90 \%$ & 0 & Highly Resistant \\
\hline MAUS $609 \times$ DS 9814 & 60 & 48 & $80 \%$ & 0 & Highly Resistant \\
\hline JS $335 \times$ DS 9712 & 60 & 50 & $83 \%$ & 0 & Highly Resistant \\
\hline JS $335 \times$ DS 9814 & 70 & 62 & $88 \%$ & 0 & Highly Resistant \\
\hline
\end{tabular}

Table.4 Disease response of $\mathrm{F}_{2}$ plants against YMV caused disease

\begin{tabular}{|c|c|c|c|}
\hline Cross Combination & $\begin{array}{l}F_{2} \text { plants } \\
\text { Screened } \\
\text { (Number) }\end{array}$ & $\begin{array}{l}\text { Resistant plant } \\
\text { against YMD } \\
\text { (Number) }\end{array}$ & $\begin{array}{c}\text { Susceptible plants } \\
\text { for YMD } \\
\text { (Number) }\end{array}$ \\
\hline MAUS $609 \times$ DS 9712 & 200 & 153 & 47 \\
\hline MAUS $609 \times$ DS 9814 & 150 & 115 & 35 \\
\hline JS335 × DS9712 & 112 & 90 & 22 \\
\hline JS335 × DS 9814 & 170 & 123 & 47 \\
\hline
\end{tabular}


Table.5 Chi Square test to check goodness of fit of $F_{2}$ plant to Mendelian ratio

\begin{tabular}{|c|c|c|c|c|c|c|c|c|}
\hline Cross Combination & $\begin{array}{l}\text { Number of } \\
F_{2} \text { plants } \\
\text { screened }\end{array}$ & $\begin{array}{l}\text { Phenotypic } \\
\text { class }\end{array}$ & $\begin{array}{l}\text { Expected number } \\
\text { of plants as per } \\
\text { Mendelian ratio } \\
\text { 3:1 }\left(\mathrm{E}_{\mathrm{i}}\right)\end{array}$ & $\begin{array}{l}\text { Observed } \\
\text { Number of } \\
\text { Plants }\left(\mathrm{O}_{\mathrm{i}}\right)\end{array}$ & $\mathbf{O}_{\mathrm{i}}-\mathrm{E}_{\mathrm{i}}$ & $\left(\mathbf{O}_{\mathrm{i}^{-}} \mathrm{E}_{\mathrm{i}}\right)^{2}$ & $\frac{\left(\mathrm{O}_{\mathrm{i}^{-}} \mathrm{E}_{\mathrm{i}}\right)^{2}}{\mathrm{E}}$ & $\chi 2=\sum_{\mathrm{i}} \frac{\left(\mathrm{O}_{\mathrm{i}}-\mathrm{E}_{\mathrm{i}}\right)^{2}}{\mathrm{E}_{\mathrm{i}}}$ \\
\hline \multirow[t]{2}{*}{ MAUS $609 \times$ DS 9712} & \multirow[t]{2}{*}{200} & $\mathrm{R}$ & 150 & 153 & 3.00 & 9.00 & 0.06 & \multirow[t]{2}{*}{0.24} \\
\hline & & $\mathrm{S}$ & 50 & 47 & -3.00 & 9.00 & 0.18 & \\
\hline \multirow[t]{2}{*}{ MAUS $609 \times$ DS 9814} & \multirow[t]{2}{*}{150} & $\mathrm{R}$ & 112.5 & 115 & -2.50 & 6.25 & 0.06 & \multirow[t]{2}{*}{0.23} \\
\hline & & $\mathrm{S}$ & 37.5 & 35 & 2.50 & 6.25 & 0.17 & \\
\hline \multirow[t]{2}{*}{ JS335 × DS9712 } & \multirow[t]{2}{*}{112} & $\mathrm{R}$ & 84 & 90 & 6.00 & 36.00 & 0.43 & \multirow[t]{2}{*}{1.71} \\
\hline & & $\mathrm{S}$ & 28 & 22 & -6.00 & 36.00 & 1.3 & \\
\hline \multirow[t]{2}{*}{ JS335 × DS 9814} & \multirow[t]{2}{*}{170} & $\mathrm{R}$ & 127.5 & 123 & 4.50 & 20.25 & 0.16 & \multirow[t]{2}{*}{0.64} \\
\hline & & $\mathrm{S}$ & 42.5 & 47 & -4.50 & 20.25 & 0.48 & \\
\hline
\end{tabular}

$\mathrm{P}_{0.05}=3.841$ at degree of freedom (d.f) $=1$.

Fig.1 Parents for hybridization

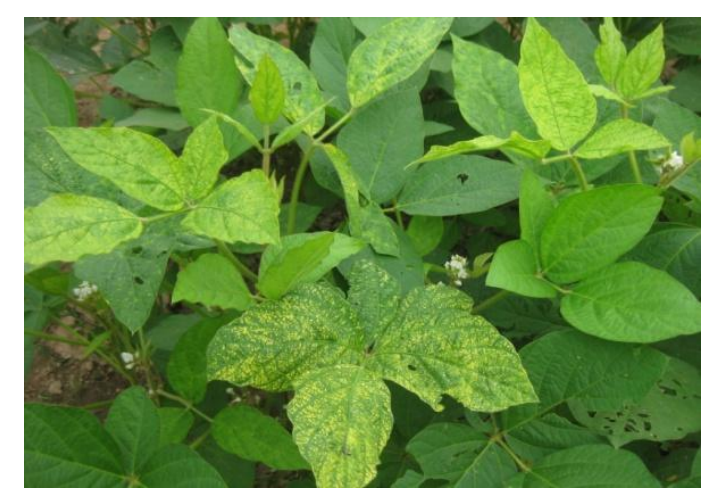

Right: Female parent: YMV resistant soybean genotype DS 9712, Left: Male parent: YMV susceptible soybean genotype JS 335 
It is also possible that different soybean genotype has different resistance mechanism (Fu et al., 2006). However, no evidence of contradictory inheritance pattern of MYMV resistance has been reported from same soybean genotypes or area.

This investigation recorded YMD resistance to be governed by single dominant gene. Hence, simple hybridization method can be used to transfer the gene to recipient genotypes followed by its selection. Elucidation of the inheritance pattern of YMD resistance will enable workers to design and identify molecular marker linked with YMD resistance gene for effective Marker Assisted Selection (MAS). This will lead to identification of the concerned gene conferring resistance to YMD.

Moreover, development of high yielding varieties devoid of YMV infection can also be attained with the help of the clear inheritance pattern. Breeding for cultivars with resistance is suggested to be very effective in controlling and preventing viral diseases of plants (Sudha et al., 2013). A better understanding about the genetic background of resistance against YMD will enable breeders to incorporate resistance into agronomically poor but desirable genetic resources. This will lead to the development of improved varieties with better yield, withstanding the viral infection. The result of the present study suggested that the resistant sources viz., DS 9712 and DS 9814 may be used in back cross breeding programme to transfer the resistance gene into the high yielding but disease susceptible varieties. Recently, two Simple Sequence Repeat markers have been found to be linked with the gene for YMD resistance in Soybean (Glycine $\max$ L. Merr) by the approach of association breeding (Kumar, 2013). Molecular markers linked to resistance against YMV and SMV (Soybean Mosaic Virus) was reported in blackgram too
(Souframanien and Gopalakrishna, 2006; Ma et al., 2010). Thus, the above genotypes (both susceptible and resistant) may also be used for identification of the particular resistance gene and its mapping on the chromosome.

\section{Acknowledgement}

The authors are grateful to the Advanced Level Institutional Biotech Hub, BN College of Agriculture, Assam Agricultural University for providing the laboratory facilities, field facilities and laboratory consumables to carry out the study.

\section{References}

Ammavasai, S., Phogat, D.S. and Solanki, I. S. 2004. Inheritance of resistance to mungbean yellow mosaic virus (MYMV) in green gram [Vigna radiata (L.) Wilczek]. Indian J. Genet. 64, 146.

Basak, J., Kundagrami, S., Ghose, T.K. and Pal, A. 2004. Development of Yellow Mosaic Virus (YMV) resistance linked DNA marker in Vigna mungo from populations segregating for YMV-reaction. Mol Breed. 14(4), 375-383.

Bhattacharyya, P.K., Ram, H. and Kole, P.C. 1999. Inheritance of resistance to yellow mosaic virus in inter-specific crosses of soybean. Euphytica. 108, 157-159.

Fauquet, C.M. and Stanley, J. 2003. Geminivirus classification and nomenclature; progress and problems, Ann Appl Biol. 142, 165-189.

Fu, S.X., Zhan, Y., Zhi, H.J., Gai, J.Y. and $\mathrm{Yu}$, D.Y. 2006. Mapping of SMV resistance gene Rsc-7 by SSR markers in soybean. Genetica. 128, 63-69.

Khattak, G. S. S., Haq, M. A., Ashraf, M. and Elahi, T. 2000. Genetics of mungbean yellow mosaic virus (MYMV) in 
mungbean (Vigna radiata $\mathrm{L}$.). J Genet Breed. 54, 237-243.

Lal, S.K., Rana, V.K.S., Sapra, R.L. and Singh, K.P. 2005. Screening and utilization of soybean germplasm for breeding resistance against Mungbean Yellow Mosaic Virus. Soybean Genetics Newsletter (32). http://soybase.org:8083/articleFiles/45.

Ma, Y., Li, H.C., Wang, D.G., Liu, N. and Zhi, H.J. 2010. Molecular mapping and marker-assisted selection of soybean mosaic virus resistance gene RSC12 in soybean. Legume Genomics and Genetics. 1, 41-46.

Panse, V.G. and Sukhatme, P.V. 1967. Statistical Methods for Agricultural Workers, ICAR, New Delhi.

Saleem, M. Haris, W.A.A. and Malik, I. A. 1998. Inheritance of yellow mosaic virus in mungbean (Vigna radiata $\mathrm{L}$. Wilczek). Pak. J. Phytopath. 10, 30-32.

Sandhu, T.S., Brar,.J.S., Sandhu, S.S., Verma, M.M. 1985. Inheritance of resistance to mungbean yellow mosaic virus in greengram. Journal of Research Punjub Agricultural University. 22, 607-611

Singh, B.B. and Mallick, A.S. 1978. Inheritance of resistance to Yellow Mosaic in soybean. Indian J Genet. 38, 258-261.

Souframanien, J. and Gopalakrishna, T. 2006. ISSR and SCAR markers linked to the mungbean yellow mosaic virus
(MYMV) resistance gene in blackgram (Vigna mungo L. Hepper). Pl Breeding. 125, 619-622.

Sudha, M., Karthikeyan, A., Anusuya, P., Ganesh, N.M., Pandiyan, M., Raveendran, M., Nagarajan, P., Angappan, K. and Senthil, N. 2013. Inheritance of Resistance to Mungbean Yellow Mosaic Virus (MYMV) in Inter and Intra Specific Crosses of Mungbean (Vigna radiate) Ame J Plant Sci. 4, 1924-1927.

Talukdar, A. and Shivakumar, M. 2012. Pollination without emasculation: an efficient method of hybridization in soybean (Glycine $\max$ (L.) Merrill). Curr. Sci. 103, 628-630.

Talukdar, A., Harish, G.D., Shivakumar, M., Kumar, B., Verma, K., Lal, S.K., Sapra, R.L. and Singh, K.P. 2013. Genetics of yellow mosaic virus (YMV) resistance in cultivated soybean (Glycine $\max \mathrm{L}$. Merr.). Legume Res. 36(3), 263-266.

Usharani, K.S., Surendranath, B., Haq, Q.M.R. and Malathi, V.G. 2004. Yellow Mosaic Virus infecting soybean in northern India is distinct from the species-infecting soybean in Southern and western India. Curr. Sci. 86(6), 845. Verma, R.P.S. and Singh, D.P. 1988. Inheritance of Resistance to Mungbean Yellow Mosaic Virus in Greengram. Annals of Agril Res. 9(3), 98-100.

\section{How to cite this article:}

Baruah, S., M.K. Sarma and Baishya, D. 2018. Genetics of Yellow Mosaic Virus Disease Resistance in Soybean (Glycine max L. Merr.). Int.J.Curr.Microbiol.App.Sci. 7(08): 47794786. doi: https://doi.org/10.20546/ijcmas.2018.708.502 